a British vessel with a combined French and British crew, and in her he rendered valuable service by preventing the establishment of enemy submarine bases in the desolate harbours of the west of Scotland which he knew so well.

After the War, Charcot continued to visit East Greenland on summer training cruises with young French sailors. He made a trip to Scoresby Sound in 1931 to select a site for the French station for the Polar Year observations of 1932-33, and afterwards transported the party of French physicists to and from the Sound. He rendered willing and efficient help to many of the recent Greenland expeditions. To young explorers Charcot was always a generous friend and a wise counsellor, and he gave the full benefit of his experience to Mr. Rymill of the British Graham Land expedition which is now in the field.

Charcot was a man of great personal charm and high culture. His literary style was clear and graceful, and his speeches on his many visits to England were always bright and to the point, for he had a perfect command of the English language and a gift for making enduring friendships. Apart from his scientific writings and his polar narratives, he was the author of a very attractive book on Christopher Columbus in which historical critics recognized the value of the interpretation of Columbus's voyages by a scientific man with a practical knowledge of seafaring.

Charcot's genius won for him full recognition as a leading man of science both at home and abroad. He was a member of the Institut de France and of the Academies of Sciences and Marine, received the gold medals and honorary membership of all the chief geographical societies of the world, and at the time of his death was president of the Paris Geographical Society.

Hugh Robert Mrri.

\section{Dr. A. Anderson}

Dr. Auexander Anderson, whose death at the age of seventy-eight years occurred on September 5, was a physicist and mathematician of note. He was professor of experimental and mathematical physics at University College, Galway, for almost fifty years. He was one of the last holders of the joint chairs of experimental and mathematical physies, a distinction shared with Prof. Morton of Belfast, who paid a graceful tribute to him in The Times of September 10.

Dr. Anderson was born in 1858. $\mathrm{He}$ studied in Queen's College, Galway (as it was then called), and graduated in 1880. He won an entrance scholarship to Sidney Sussex College, Cambridge, in 1881. $\mathrm{He}$ was sixth wrangler in 1884. After a short period in the Cavendish Laboratory under Sir J. J. Thomson, he was appointed professor at Galway in 1885. $\mathrm{He}$ became president there in 1899 and held both offices until his resignation in 1934.

Anderson is perhaps best known for his method of measuring self-inductance, which is in general use in laboratories of physics and electrical engineering. Two other of his methods have become standard practice, namely, his method of measuring surface tension and his method of measuring the viscosity of a gas. From 1890 onwards he published many papers in experimental and mathematical physics on optics, electrostatics, electromagnetics and relativity. Of his researches in experimental physics, possibly the most important is his contribution to the theory of contact differences of potential. In mathematical physics his papers mainly deal with new methods of approach to older theory.

The remarkable thing about Anderson was his really wide knowledge of experimental and mathematical physics and his continuous keenness as a teacher, especially of advanced students. I remember hearing the late Prof. McClelland, his most distinguished student, state many years ago that it was usual for his advanced lectures on mathematical physics to go on continuously for three hours, and this was his practice almost up to his retirement. He simply revelled in physical and mathematical problems. Personally Dr. Anderson was a most kindly man with a marked sense of humour. M. P.

\section{Prof. Antoine Meillet}

WE regret to record the death of M. Antoine Meillet, professor of philology at the Collège de France, and president of the Historical and Philological Faculties at the Ecole des Hautes Études, Paris, which took place at Châteaumeillant (Cher) on September 22, at the age of seventy years. Prof. Meillet was born at Moulins (Allier) on November 11, 1866. He became a lecturer in the École des Hautes Etudes in 1891. From 1904 until 1906 he was a professor of the Ecole des Langues Orientales Vivantes and in the latter year was appointed to the chair of comparative philology in the Ecole de France. M. Meillet was regarded as one of the most eminent philologists of the day, his researches extending over the whole field of the Indo-European and Iranian languages. His "Introduction à l'Etude Comparative des Langues Européennes", first published in 1897, has been through many editions, the last appearing in 1934.

\section{WE regret to announce the following deaths :}

Prof. Henry Le Chatelier, For. Mem. R.S., and honorary fellow of the Chemical Society, on September 17, aged eighty-five years.

Brig.-General Sir Brodie Haldane Henderson, K.C.M.G., C.B., president in 1928-29 of the Institution of Civil Engineers, who designed the Lower Zambezi Bridge, on September 28, aged sixty-seven years.

Lieut-Colonel R. Knowles, C.I.E., acting director of the Calcutta School of Tropical Medicine, known for his work on medical protozoology, on August 3, aged fifty-two years.

Dr. A. H. Mackenzie, C.S.I., C.I.E., pro-ViceChancellor of the Osmania University, Hyderabad, who was a member of the recent Quinquennial Reviewing Committee of the Indian Institute of Science, Bangalore, on September 26, aged fifty-six years. 